\author{
Ádám Smrcz \\ University of Public Service, Budapest, Hungary \\ ORCID: 0000-0001-9249-7699 \\ e-mail: smrczadam@gmail.com
}

\title{
Nature in Progress - Tocqueville and the Transformation of Natural Law
}

\section{Introduction}

Not long after arriving in the United States did Alexis de Tocqueville recognize a social order entirely different from what he had known in France: he found not only the political, legislative, or juridical systems of the Americans' astonishing, but even their towns, their ways of living and - most importantly - their mentality were unfamiliar to him. He was amazed by their constant pursuit of self-interest, their fondness for calculating the possible outcomes of their undertakings, but it was their love of equality first of all that eventually inspired writing Democracy in America: "as I studied American society, I saw more and more, in the equality of conditions, the generating fact from which each particular fact seemed to derive" [je voyais de plus en plus, dans l'égalité des conditions, le fait générateur dont chaque fait particulier semblait descendre.$^{1}$

Moreover, many of the effects produced by this generating fact turned out to be highly successful: as Alan Greenspan and Adrian Woodridge put it, prior to the 1820 s the rate of economic growth nowehere exceeded $0,11 \%$ per year (meaning that it could take a whole century for a country's GDP

1 Alexis de Tocqueville, Democracy in America (Liberty Fund, 2010), 4. 
to expand by $11 \%$, something that could happen merely within a 3-4 yearlong period in the $20^{\text {th }}$ century), ${ }^{2}$ but by the 1830s things began to change rapidly, especially in the US. ${ }^{3}$ Tocqueville also observed that people had moved away from agriculture towards the fields of commerce and industry, which were further enhanced by the expanding transportation system, ${ }^{4}$ and as he put it: "I do not even know of a country where the love of money holds a greater place in the human heart and where a deeper contempt is professed for the theory of the permanent equality of property." 5

Tocqueville immediately recognized that, owing to its success, the American system would sooner or later take roots in Europe as well: "this same democracy that reigned in American societies, appeared to me to advance rapidly toward power in Europe [me parut en Europe s'avancer rapidement vers le pouvoir]. ${ }^{6}$ It has been a matter of debate, whether Tocqueville regarded the economic efficiency of democracies as the key factor of their success, or whether there was some other reason instead, which enhanced their "advance toward power," ${ }^{7}$ while it also has been disputed whether the author regarded this "advance toward power" as sticto sensu inevitable, or, in other words, whether he endorsed the socalled inevitability thesis. ${ }^{8}$

On the contrary, it is another question of importance, whether or how much Tocquville regarded the "advance of equality" desirable! One should not forget that Tocqueville was not only a descendant of the French noblesse d'épée himself, but many of his remarks suggest that he sincerely sympathized with - what Alan Kahan and others call - an "aristocratic liberalism" ${ }^{\prime \prime}$ instead of a system entirely lacking estates.

2 Alan Greenspan and Adrian Wooldridge, Capitalism in America (Penguin Publishing Group, 2018), 12.

3 Richard Schwedberg, Tocqueville's Political Economy (Princeton: Princeton University Press, 2009), 9.

4 Ibidem, 10.

5 Tocqueville, Democracy in America, 85.

6 Ibidem, 5.

7 Schwedberg, Tocqueville's Political Economy, 9.

8 Marvin Zetterbaum, "Tocqueville: Neutrality and the Use of History", The American Political Science Review 58, 3 (Sep., 1964): 611-621.

9 According to Kahan, Tocqueville had deep concerns regarding egalitarian democracies for three interconnected reasons: individualism, materialism and the tyranny of the majority. A society lacking estates might be harmful for the solidarity between citizens, who would spend more of their energy striving for material goods, and less estabishing human connections. And such a society would be prone to fall prey to tyrants, since individuals in themselves could not hinder their ambitions. Alan S. Kahan, Aristocratic Liberalism (Oxford: Oxford University Press, 1992); Alan S. Kahan, Alexis de Tocqueville (New York: The Continuum Inter- 
Although the above mentioned claims seem to be contradictory to each other, a number of scholars still hold that they are not stricto sensu contradictions, but only highlight Tocqueville's inner struggles between his personal convictions and the conclusions he drew from his historical findings. According to such interpretations, one should differentiate between what Tocqueville held desirable and inevitable, between what ought to happen according to him and what will come to pass anyway. While the aristocratic liberal ideal might have been Tocqueville's personal conviction, he might have still held the inevitability thesis to be true. Such an interpretation is consistent with what Hayden White proposed in his 1973book, Metahistory: The Historical Imagination in Nineteenth-Century Europe. White famously regarded Tocqueville as a representative of the "tragic emplotment" of history, namely someone who saw historical events with resignation as to their inevitability. Tocqueville - according to White - employed a "mechanical-causal" way of explaining historical phenomena, as a result of which "he viewed the whole historical process as a closed system, containing a finite amount of usable energy, in which whatever is gained in any process of growth must be paid for by some loss in another part of the system", and as a result of which he "suggested that the decline of the aristocratic type is a function of the rise of the democratic type."10

The aim of this paper is to argue that White's interpretation of Tocqueville is correct, but our arguments will be based on a subject entirely ignored by White: Tocqueville's scanty remarks on nature and natural law. According to their commonsensual definition, natural laws must "stem from God, nature or reason,"11 but this relationship in Tocqueville is highly problematic. ${ }^{12}$ As we shall see, Tocqueville probably did acknowledge the existence of natural laws, and even intended to describe their resulting obligations (as in the case of what virtuous deeds are, or what humanity is etc.), but the way he defined nature herself suggests that the precise content of such obligations cannot be settled easily. Hence, according to our claim, a disturbing tension can be observed between the way Tocqueville attempted to describe certain natural laws, and the way he defined natural laws in general. Furthermore, this tension is analogous with the

national Publishing Group Inc., 2010), 37; Annelien de Dijn, French Political Thought from Montesquieu to Tocqueville (New York: Cambridge University Press, 2008).

10 Hayden White, Metahistory: The Historical Imagination in Nineteenth-Century Europe (Baltimore: Johns Hopkins University Press, 1973), 195.

11 Hans Kelsen, General Theory of Law and State (London: Oxford University Press, 1949), 392.

12 Regarding Tocqueville's supposed non-belief see: Kahan, Alexis de Tocqueville, 30-31. 
aforementioned friction between the author's personal convictions and his scientific conclusions.

Our train of thought will be the following: (1) first we shall outline White's interpretation of Tocqueville. Here, we shall argue that White rightly regarded Tocqueville as a "mechanical-causal" thinker, and, by consequence, Tocqueville must have regarded the decline of the hereditary aristocracy as an inevitable outcome of the success of the American economic system and social order (something less than desirable for someone with "aristocratic liberal" leanings). Next, we shall proceed to Tocqueville's views on (2.1) the concept of nature and to (2.2) its relation with the content of natural laws. Here, we shall see a tension between the positive content of natural laws and their underlying definition. As we shall see, Tocqueville (p1) set human nature in motion, and since (p2) virtues must be grounded in human nature, (c) no constant definition can be given to (most) particular virtues.

According to our overall claim, Tocqueville endorsed the inevitability thesis not, or not only, because historical facts led him to this conclusion, but because he must have regarded this step as a necessary condition for escaping the trap of ethical relativism, and finding solid foundations for natural laws.

\section{Tocqueville's place in White's taxonomy}

Hayden White's Metahistory deals not with historical facts or empirical data, but is concerned exclusively with the fictional layer of historiographical works. Owing to this methodology, White focuses solely on the linguistic structure of these texts, and in order to uncover the underlying components by which explanatory force is given to such narratives, he makes a threefold distinction between (1) emplotment; (2) formal reasoning; (3) ideological implications. Each of these - according to White - contributes to the way historical events are organized into a meaningful whole, and consequently, they also determine how the narrative (the "meaningful whole") will represent these events.

\subsection{Emplotment}

According to White's famous observation, historiography, as we know it, came into being as a result of a productive misunderstanding: the most rudimentary form of emplotment can be traced back to the texts of chronicles or annales, which contained purely empirical facts in such a way, that 
consecutive events were simply arranged below each other. The misunderstanding arose from this typographical method: although the events listed in these texts were - mostly - causally independent of each other, but readers still tended to attribute causal relationship to them, and following a post hoc, ergo propter hoc way of logic, the (first core of the) emplotment was born. ${ }^{13}$ According to White, such attribution of attitudes, causal relationship etc. to events is part of the emplotment, which, in turn, stems from the historian, not from the historical facts themselves.

Following Northrop Frye, White made a fourfold distinction between the certain types of emplotment: (1.1) Romance, (1.2) Tragic, (1.3) Comic, and (1.4) Satirical. This distinction is based on what sort of capacity a certain historian attributes to his heroes: do they have the ability or the intention to oppose the forces of nature or not? In the (1) case of Romance, a hero is completely able to overcome the forces of nature or the obstacles he or she has to face; in the second (2) and (3) third cases, the hero is either forced to put up with the fact that he or she (2) cannot overcome the opposing forces (3) or needs to find a solution which has the appearance of being a solution; finally, in the case (4) of the Satire, the author portrays his hero as someone incapable of finding the right solution right from the beginning. White regards Tocqueville as someone clearly belonging to the second or Tragic (1.2) type of emploters, owing to his portrayal of democracy as something undesirable and inevitable at the same time.

The whole process has the inevitability of a Tragic Drama, and Tocqueville's early reflections on history and historical knowledge explicitly envisioned the task of the historian as that of a mediator between the new, conquering forces appearing on his own temporal horizons and the older, languishing cultural ideals which they threaten by their ascent. ${ }^{14}$

\subsection{Formal reasoning}

The historian's task, however, cannot be confined to mere emplotment, since in this case, history would not differ from literature at all. Hence, at least to some extent, the historian needs to reflect on the causal relationships he attributes to his subject matter. White makes a fourfold distinction between the historians in this regard as well and classifies them into groups that he calls (2.1) formist, (2.2), organicist, (2.3), mechanist, and

13 White, Metahistory: The Historical Imagination in Nineteenth-Century Europe, 103-143.

14 Ibidem. 
(2.4) contextualist. While (2.1) formist historians - according to White emphasize individual features of events, things, or persons, (2.2) organicist narratives highlight analogies between events at a micro and macro level. (3.3) Mechanist historians interpret events merely as instances of different natural laws, while (2.4) contextualist narratives examine events from a presentist perspective. Within this taxonomy of formal reasoning, White finds Tocqueville's place among the (3.3) mechanist historians, but he also adds, that mechanist historiography - owing to its philosophical implications which cannot be proved on historical grounds - has mostly been regarded by academic historians as unscientific, ${ }^{15}$ and hence, it is more closely related with the philosophy of history.

\subsection{Ideological implications}

So far, we have seen that White regards Tocqueville as a representative of the (1.2) Tragic way of emplotment, who employed a (2.3) mechanist way of formal reasoning. Having defined the Tragic way of emplotment as something where the hero cannot overcome the opposing forces of nature, and also having defined the mechanist way of formal reasoning as a practice which puts an emphasis on the force of natural laws (instead of the ability of the heroes), all this suggests a high level of consistency in Tocqueville's thinking.

White, furthermore, holds Tocqueville to be consistent from the point of view of his ideological implications as well. As for such ideological implications, White draws up a fourfold distinction once more: these are (3.1) conservative, (3.2) liberal, (3.3) radical and (3.4) anarchist leanings. As he says, "[w]ith respect to the problem of social change, all four recognize its inevitability, but represent different views as to both its desirability and the optimum pace of change."16 (3.1) Conservatives - according to White regard society as analogous to a living organism, and, hence, oppose the sudden implementation of novel policies. (3.2) Liberals, although without endorsing the metaphor of the living organism, are also commited to "fine tuning" instead of radical change. (3.3.) Both of these groups are opposed by the radicals, who "envision cataclysmic transformations", and their view is also shared by (3.4) the anarchists, who endorse the idea of rapid change. Regarding Tocqueville, it was one of White's most unorthodox claims, that the author of the Democracy in America belonged to the (3.3) radical type of historians:

15 Ibidem, 863-899.

16 Ibidem, 24. 
[i]n fact, it is my contention that the actual logical implication of Tocqueville's work as a historian is Radical. Inasmuch as he studied history in order to determine the causal laws that govern its operations as a process, he was implicitly committed to a conception regarding the manipulation of the social process of the sort that we associate with Radicalism in its modern, materialistic form. This implicit Radicalism is reflected in the Tragic mythos that underlies and provides the macrohistorical context of both of Tocqueville's major works, Democracy in America and The Old Regime and the Revolution. ${ }^{17}$

For White, Tocqueville, as a historian was a radical because he endorsed the idea of reforming French society in order to create adequate circumstance for the democracy, that would inevitably arrive to France one day as well. However, it is important to note, that White only spoke here of Tocqueville only "as a historian", not of Tocqueville as a private person.

\section{The nature of nature in Tocqueville?}

\subsection{The concept of nature}

Having seen White's interpretation, let us turn our attention to a crucial question of the Democracy in America, which may confirm White's hypothesis. The question at hand is the so-called "inevitability thesis", namely whether Tocqueville in fact regarded the spread of democracy as something inevitable, and in order to examine whether historical events were (pre)determined according to Tocqueville, one must first uncover the author's stance on determinism in general. He only occasionally brings this topic forward, and in these cases he discusses it under the key words of fatality (sort, destin, fatalité), divine providence (providence), and nature (nature).

Even at first sight, it is fate, by which Tocqueville seems to refer to events which are entirely inevitable. In the Introduction of the Democracy in America, for instance, he speaks of the fate of Christian peoples of the world, whose "fate is in their hands; but soon it escapes them." ${ }^{18}$ This only means that at one point people can have a causal effect on the outcome of certain events, while at a later point, they cannot. Moreover, in a later chapter of his treatise, Tocqueville speaks of historians "of the democratic age" who "take away from peoples themselves the ability to modify their

17 Ibidem, 193.

18 Tocqueville, Democracy in America, 15. 
own fate, and subject them either to an inflexible providence or to a sort of blind fatality," ${ }^{19}$ but he clearly does not endorse their point of view. These claims, hence, do not postulate the "inevitability thesis" at all, since they imply some ability of people to alter the course of events. Tocqueville's few remarks on fate, therefore, do not contribute too much to the understanding of his overall views on determinism.

On the contrary, a closer look at Tocqueville's views on providence and nature can make a different impression! In the case of Tocqueville, these two concepts are closely interrelated, which can be seen from the Introduction to the Democracy, where he expresses a perplexing stance on this subject:

It is not necessary for God himself to speak in order for us to discover sure signs of His will; it is enough to examine the regular march of nature and the continuous tendency of events [il suffit d'examiner quelle est la marche habituelle de la nature et la tendance continue des événements]; I know, without the Creator raising his voice, that the stars in space follow the curves traced by His fingers. ${ }^{20}$

The perplexity of this remark stems not so much from the idea that God's will can be accessed through the observation of His creatures, but from the metaphor of nature in progress. What Tocqueville means by nature here is obviously not a set of eternally fixed physical laws, but rather non-physical events that are in a constant stage of change. Comparing this stance with claims from classical natural law, the difference will be even more striking, so much so that one easily gets the impression that Tocqueville's phrasing amounts even to a contradiction in terms! Let us recall, for instance, Hugo Grotius' etiamsi daremus argument, claiming that the definite laws of nature would remain in force even if God did not exist:

What we have been saying would have a degree of validity even if we should concede that which cannot be conceded without the utmost wickedness: that there is no God, or that the affairs of men are of no concern to Him. ${ }^{21}$

The difference is twofold: first, Grotius allowed for the possibility that God did not exist, and, in consequence, he was not the one who determined the laws of nature. Tocqueville does not (explicitly) concede

19 Ibidem, 857-858.

20 Ibidem, 14.

21 Hugo Grotius, On the Law of War and Peace, ed. Stephen C. Neff (Cambridge: Cambridge University Press, 2013). 
to such an idea. Second, for Grotius, the contents of natural law are fixed, which is a necessary condition for their graspablity. This is a crucial momentum, since, without being able to grasp the contents of natural laws, the latter could not be morally binding. As opposed to this, Tocqueville speaks only of the "march of nature", which is prima facie problematic with regard to the idea of attributing any fixed content to natural laws, while it also obscures what normative demands could be derived from such floating principles.

However, we can ignore the first difference on the basis that it is highly unlikely that God played a substantial role in Tocqueville's political philosophy: $: 22$ although the author refers to God and divine providence in a number of occasions, these references should not be taken at face value even if our doubts concerning Tocqueville's personal belief in God proved to be ungrounded. Moreover, as we can see at one point in the Ancient Regime and the Revolution, for instance, the author speaks about customs based on "simple principles, derived from reason and natural law," 23 and hence discusses natural law without any reference to God as its possible source. And if this latter stance is what mirrors Tocqueville's actual views on natural law, we could even say that he adhered to the Grotian etiamsi daremus in this methodological respect.

Still, the second difference remains haunting: if the "march of nature" is really supposed to mean that the laws of nature are in constant change, this might even amount to disavowing the possibility of natural laws. According to our claim, however, Tocqueville's reference to nature as to the source of true and righteous knowledge (the "sure sign of God's will") is more than a mere epitheton ornans or captatio benevolentiae (like his aforementioned references to God), and it has to be taken seriously. In our view, Tocqueville identified nature with history. This is mirrored by many of his remarks, concerning "natural taste", for instance, which is not natural in our sense (meaning: it is not universal), but conditioned by some particular circumstance instead. "I think that democratic peoples have a natural taste for liberty" 24 - as he claimed in the Democracy, but elsewhere he also spoke about the "natural taste for equality of conditions and uniformity of rules" among peoples in democracies. ${ }^{25}$

Nature, here, is not supposed to be taken in the sense of natura naturans or as a cause producing effects by itself, but rather as natura naturata, an

22 Kahan, Alexis de Tocqueville, 30-31.

23 Alexis de Tocqueville, The Ancien Régime and the French Revolution (Cambridge: Cambridge University Press, 2011), 128.

24 Tocqueville, Democracy in America, 878.

25 Tocqueville, The Ancien Régime and the French Revolution, 146. 
effect that follows from something else, which is, in this case, nothing else than history. This is a point where - what White called - the mechanist kind of formal reasoning is clearly palpable in Tocqueville: different historical circumstances produce different dispositions in human nature. But this mechanistic view - as we have already said - is highly problematic, since it is human nature which is supposed to be the source of natural law. And if human nature is altered from time to time, the latter can have no immutable basis.

Tocqueville seems to be aware of this hardship, and he visibly intends to solve it. The author, for instance, leaves no doubt right from the beginning of the Democracy in America, that all the unfamiliar customs he witnessed in the New World can be traced back to one single cause, or "generating fact" as he calls it, which is the "equality of conditions".

As I studied American society, I saw more and more, in the equality of conditions, the generating fact from which each particular fact seemed to derive [dans l'égalité des conditions, le fait générateur dont chaque fait particulier semblait descendre], and I rediscovered it constantly before me as a central point where all of my observations came together. ${ }^{26}$

So far, so good, but this claim can only guarantee that identical circumstances (viz. a democracy) will produce identical effects or dispositions in human nature, and it leaves the door open for criticism, since it does not identify the "generating fact" of human nature in general.

And this is where the inevitability thesis is really at stake! Although Tocqueville admittedly failed to find a more fundamental cause of human dispositions than the aforementioned one, he visibly held this cause to be (or to become) universal. As he said:

the gradual development of equality of conditions is a providential fact [le développement graduel de l'égalité des conditions est donc un fait providentiel]; it has the principal characteristics of one: it is universal, it is lasting, it escapes every day from human power [il échappe chaque jour à la puissance humaine]; all events, like all men, serve its development. ${ }^{27}$

As we have previously said, the author's reference to divine providence is not a substantial part of his argument, which claim is reinforced here once more: although he speaks about a "providential fact", he also defines it in secular terms (it is "universal", "lasting" and "escaping from human power"). But even more importantly, the author overtly claims that it is the

26 Tocqueville, Democracy in America, 4.

27 Ibidem, 11-12. 
"development of equality of conditions" which is "universal", "lasting" and "escaping from human power". All this suggests that, while Tocqueville had to admit to a relativist claim (that only identical circumstances can produce identical dispositions in human nature), he intended to tame this view by claiming that the circumstances themselves will inevitably become identical as well.

\subsection{The positive content of natural law}

This passage by Tocqueville serves maybe as the strongest argument on behalf of his endorsemnt of the inevitability thesis, but it can also funtion as the grounding of natural law, since it implies that human nature, which was originally en marche, will be settled one day. Or, to put it differently: the author could only hope for establishing a natural law theory if he did in fact accept the inevitability thesis.

But how sincerely did Tocqueville try to establish such a theory in detail? The reader's first and unquestionable impression is that the author's remarks on the subject are scarce and scattered, hardly ever using the terms "natural law" or "laws of nature". This has led some scholars to the conclusion that Tocqueville's actual aim was the elimination of natural law from political theory. ${ }^{28}$ Others, however, claim that Tocqueville had no such intention, but intended to detail the positive content of some obligations derived from natural law instead. For instance, Marek Tracz-Tryniecki enumerates a number of cases where Tocqueville seems to speak about moral concepts which were cherished, not only by a particular group of people, but by the majority of mankind as well (e.g. justice, humanity). In a number of such cases, the author even seems to endorse the idea, that a moral principle grounded in natural law should override principles based merely on custom, ${ }^{29}$ a view entirely consistent with the demands of classical natural law.

On the basis of what we have seen so far, such assumptions are highly problematic from Tocqueville's point of view: even if the "development of equality of conditions" may become a universal phenomenon one day (something the author seems to admit to), we are not yet in a position from where one could describe the contents of the particular natural laws.

28 Ken Masugi, Citizens and Races - Natural Rights Versus History, in: Tocqueville's Defense of Human Liberty - Current Essays, eds. Peter Augustine Lawler, Joseph Alulis (New York: Garland Publishing, 1993).

29 Marek Tracz-Tryniecki, "Natural Law in Tocqueville's Thought", Journal of Markets $\mathcal{E}$ Morality 11, 1 (Spring 2008): 27-40. 
Moreover, Tracz-Tryniecki's claim is reinforced by some really explicit and no less disturbing remarks by Toqueville. At a certain point in the Democracy in America, for instance, he claimed that some moral failings are characteristic of the whole of mankind, and this has been universally recognized as well.

Humanity feels permanent and general needs, which have given birth to moral laws; to their disregard all men have naturally attached, in all places and in all times, the ideas of blame and shame. They have called it doing evil to evade them, and doing good to submit to them. ${ }^{30}$

This claim is consistent with the basic tenets of classical natural law once more, but is it consistent with Tocqueville's own assumptions? As we have seen, only identical circumstances have the ability produce identical dispositions in human nature. If some dispositions have been shared by people "in all places and in all times" - as the author says - it entails that at least certain circumstances must have been identical. But such a claim is, even if not contradictory to, in conflict with Tocqueville's previously seen assumptions.

\section{Conclusions}

According to our argument, Tocqueville failed to provide a fully consistent theory of nature and natural law. However, some self-contradiction can still reveal important aspects of an author's commitments and way of thinking. As we have seen, Hayden White placed Tocqueville among historians who bore a tragic attitude towards their subject, employed a "mechanical-causal" way of explanation, and endorsed a radical stance. In this paper, we have mostly focused on whether Tocqueville was in fact a "mechanical-causal" thinker, and our answer was affirmative. However, by accepting the inevitability thesis, a claim according to which events happen in a mechanical and deterministic way, he had to reach conclusions which might have been highly undesirable for him. His inconsistencies can be attributed to his personal reluctance to accept what he, as a historian percieved to be inevitable.

30 Tocqueville, Democracy in America, 1094. 


\section{Bibliography}

Dijn Annelien de. 2008. French Political Thought for Montesquieu to Tocqueville. New York: Cambridge University Press.

Greenspan Alan, Adrian Wooldridge. 2018. Capitalism in America. Penguin Publishing Group.

Grotius Hugo. 2013. On the Law of War and Peace, ed. Stephen C. Neff. Cambridge: Cambrige University Press.

Kahan Alan S. 1992. Aristocratic Liberalism. Oxford: Oxford University Press.

Kahan Alan S. 2010. Alexis de Tocqueville. New York: The Continuum International Publishing Group Inc.

Kelsen Hans. 1949. General Theory of Law and State. London: Oxford University Press.

Masugi Ken. 1993. Citizens and Races - Natural Rights Versus History. In: Tocqueville's Defense of Human Liberty - Current Essays, eds. Peter Augustine Lawler, Joseph Alulis. New York: Garland Publishing.

Schwedberg Richard. 2009. Tocqueville's Political Economy. Princeton: Princeton University Press.

Tocqueville Alexis de. 2010. Democracy in America. Liberty Fund.

Tocqueville Alexis de. 2011. The Ancien Régime and the French Revolution. Cambridge: Cambridge University Press.

Tracz-Tryniecki Marek. 2008. "Natural Law in Tocqueville's Thought". Journal of Markets $\mathcal{E}$ Morality 11, 1.

White Hayden. 1973. Metahistory: The Historical Imagination in Nineteenth-Century Europe. Baltimore: Johns Hopkins University Press.

Zetterbaum Marvin. 1964. "Tocqueville: Neutrality and the Use of History". The American Political Science Review 58, 3: 611-621.

\section{Summary}

Hayden White famously claimed that Tocqueville's emplotment of history was "tragic" by genre, and his ideological implications were "radical". The aim of this paper is to argue that this interpretation is correct, but that our arguments will be based on a subject entirely ignored by White: Tocqueville's meagre scarce remarks on nature and natural law. According to their commonsensical definition, natural laws must "stem from God, nature, or reason", but this relationship in Tocqueville is highly problematic. As I intend to prove, Tocqueville probably did acknowledge the existence of natural laws, and even intended to describe their resulting obligations (as in the case of what virtuous deeds are, or what humanity is etc.), but the way he defined nature herself suggests that the precise content of such obligations cannot be settled easily. Hence, according to our claim, a disturbing tension can be observed between the way Tocqueville attempted to describe 
certain natural laws, and the way he defined natural laws in general. Furthermore, this tension is analogous with the aforementioned friction between the author's personal convictions and his scientific conclusions.

Keywords: Alexis de Tocqueville, Hugo Grotius, Hayden White, natural law, idea of progress 